\title{
Germination and Seedling Growth of Tall Wheat- grass and Basin Wildrye in Relation to Boron
}

\author{
BRUCE A. ROUNDY
}

\section{Abstract}

Seedling establishment on many saline, arid rangeland soils in the Great Basin may be limited not only by low soil osmotic and matric potentials, but also by high boron concentrations. Germination and seedling growth of tall wheatgrass [Agropyron elongatum (Host) Beau. 'Jose'] and basin wildrye (Elymus cincereus Scribn. and Merr. 'Magnar') were measured in relation to increasing boron concentrations in laboratory and greenhouse experiments. Rate and total germination of both species were unaffected by boron concentrations up to $200 \mathrm{ppm}$, while radicle length was unaffected at less than $100 \mathrm{ppm}$. Growth of both species was much more sensitive to boron than was germination. Root growth of both species was more sensitive to boron than shoot growth. Shoot growth of Jose tall wheatgrass was less sensitive to boron than that of Magnar basin wildrye. Reduction in root and shoot yield of $50 \%$ occurred at soil saturation extract concentrations of 30 and $66 \mathrm{ppm}$ of boron, respectively, for Jose tall wheatgrass, and 22 and $37 \mathrm{ppm}$ of boron, respectively, for Magnar basin wildrye. Boron concentrations ranging up to $97 \mathrm{ppm}$ in the saturation extract of a typical Great Basin saline soil in central Nevada would probably affect seedling growth and survival, but not emergence of these species. The fact that Jose tall wheatgrass has greater absolute root growth and boron tolerance than does Magnar basin wildrye may account, in part, for its greater seedling survival on a saline soil in central Nevada.

Many saline/alkaline rangelands in the arid West can be highly productive once adapted forage species are established. In addition to high sodium concentration and low osmotic and matric potentials, high boron concentrations may limit seedling emergence and establishment on the associated saline/alkaline, arid soils. Many Great Basin playas have accumulated boron from hot springs waters which become boron-enriched from late-stage differentiates of granitic magmas (Papke 1976). Sediments high in boron are then eroded from playa surfaces and deposited by wind on lowland soils (Young and Evans 1985). Two grasses which may have the greatest potential for establishing on these soils are tall wheatgrass [Agropyron elongatum (Host) Beau.] and basin wildrye (Elymus cinereus Scribn. and Merr.). Tall wheatgrass is well known for its sodic and salt tolerance (Dewey 1960, Carter and Peterson 1962, Shannon 1978, Roundy 1983), and the high boron tolerance of 3 cultivars, Alkar, Nebraska, and Largo, has been documented by Schuman (1969). Germination of tall wheatgrass was not decreased by $80 \mathrm{ppm}$ water soluble boron, and growth reductions to $50 \%$ occurred from 33 to $46 \mathrm{ppm}$ of boron depending on the

\footnotetext{
Author is formerly, range scientist, USDA, Agriculture Research Service, Reno, Nev. 89512, presently research associate, School of Renewable Natural Resources. University of Arizona, Tucson 85721 .

Cooperative investigation of the USDA, Agricultural Research Service, 920 Valley

Road, Reno, Nev. 89512 and the Agricultural Experiment Station, University of Nevada, Reno 89512 .

Manuscript accepted September 13, 1984.
}

cultivar and the experiment (Schuman 1969). Basin wildrye is a native grass adapted to many saline-sodic soils (Young and Evans 1981). Pratt et al. (1971) have shown basin wildrye to be tolerant to mine spoils containing $5 \mathrm{ppm}$ soluble boron in the saturation extract. An improved cultivar of basin wildrye called Magnar has much higher seed viability and germination than native wildrye collections (Evans and Young 1983) and also has high sodic and salt tolerance (Roundy 1983). However, Magnar basin wildrye had much lower emergence and establishment than Jose tall wheatgrass on a saline soil in central Nevada (Roundy 1985). Becic (1983) emphasized that greater tolerance to boron of some range plants in comparison to that of crop species and noted the lack of boronrelated research on range plants. The purpose of this study was to compare the germination of seedling growth of Jose tall wheatgrass with that of Magnar basin wildrye in relation to boron and to determine if boron concentrations on a saline soil in the Great Basin were high enough to affect seedling establishment of these species.

\section{Materials and Methods}

The germination experiment was a split-plot with completely randomized design of the whole plot portion with each replication of each boron concentration treatment (whole plot) containing both species. Twenty-five seeds of each species were placed in plastic boxes containing 5 g polystyrene foam (Young et al. 1968) and boric acid solutions containing $0,10,20,30,40,50,60,70,80$, $90,100,120,150,180,200,250,300,350,400,450,500$ ppm boron. There were 4 replications of each boron concentration or whole plot and all replicates were incubated in a dark-germinator at a constant $15^{\circ} \mathrm{C}$. Germinated seedlings were counted every 2 or 3 days for 3 weeks and radicle length of 20 randomly selected seedlings per cultivar for each boron concentration was measured at the end of 3 weeks. Seeds were considered germinated by radicle emergence of a minimum of $0.5 \mathrm{~cm}$. Average rates of germination were calculated after MaGuire (1962) where:

$$
\text { Average germination rate }\left(\% \mathrm{day}^{-1}\right)=\underset{\mathrm{i}}{\mathbf{n}}\left[\mathrm{g}_{\mathbf{n}}-\mathrm{g}(\mathrm{n}-1) / \mathrm{n}\right]
$$

in which $g$ is the total germination percentage on an incubation day $\mathrm{n}$ minus the total germination percentage on the previous day $\mathrm{g}$ (n-1) divided by the incubation day.

The seedling growth experiment was designed as a randomized complete block. Pots $11.5 \mathrm{~cm}$ diameter by $11 \mathrm{~cm}$ deep were filled with sandy loam soil and irrigated every other day with complete nutrient solution (Hoagland and Arnon 1938) and boron concentrations of $0,10,20,40,60,80$, and $100 \mathrm{ppm}$ from boric acid. Desired boron concentrations were maintained in the soil by irrigating sufficiently to leach out old solution and replace it with new 
solution. Twenty-five seeds of each cultivar were seeded separately in 4 pots each for each boron concentration and pots were finally thinned to 10 seedlings. The experiment was conducted in the greenhouse with average day and night temperatures of 30 and $20^{\circ} \mathrm{C}$, respectively; relative humidity ranged from $30 \%$ during the day to $70 \%$ at night. Soil boron concentrations were checked at the end of the experiment using a liquid exchange electrode (Carlson and Paul 1968, 1969) and were within 2 to $7 \mathrm{ppm}$ of the original boron treatment concentrations. Roots and shoots were harvested, oven dried, and weighed 45 days after seeds were sown. Cultivar responses to increasing boron concentrations were fit to polynomial regression equations and confidence intervals $(P \leq 0.05)$ were calculated according to Ott (1977).

A saline soil (electrical conductivity of the saturation extract = $7.0 \mathrm{dS} \mathrm{m}^{-1}$ ) was sampled at depth intervals of $0-1,1-5,5-10$, and $10-15 \mathrm{~cm}$ in the spring of 1981 in conjunction with a seedling establishment study (Roundy 1985) to determine the associated range of soil boron concentrations. Four samples were taken for each depth interval for soil microtopographical areas appearing high in salinity and areas appearing low in salinity as evidenced by the presence or absence of a thin salt crust on the soil surface. Water soluble boron concentrations of the saturation extracts of these soil samples were determined with a liquid ion exchange electrode (Carlson and Paul 1968, 1969).

\section{Results}

Statistically significant differences in germination and growth responses were indicated at boron concentrations where the confidence intervals ( $P \leq 0.05$ ) of estimated responses did not overlap (Table 1).

Table 1. Boron concentration associated with Jose tall wheatgrass and Magnar basin wildrye germination and growth reductions.

\begin{tabular}{|c|c|c|c|c|}
\hline \multirow[t]{3}{*}{ Variable } & \multicolumn{2}{|c|}{ Significant reduction+ } & \multicolumn{2}{|c|}{$50 \%$ reduction } \\
\hline & $\begin{array}{c}\text { Tall } \\
\text { wheatgrass }\end{array}$ & $\begin{array}{c}\text { Basin } \\
\text { wildrye }\end{array}$ & $\begin{array}{c}\text { Tall } \\
\text { wheatgrass }\end{array}$ & $\begin{array}{c}\text { Basin } \\
\text { wildrye }\end{array}$ \\
\hline & \multicolumn{4}{|c|}{$\begin{array}{c}\text { Boron concentration of soil } \\
\text { saturation extract (ppm) }\end{array}$} \\
\hline $\begin{array}{l}\text { Total germination } \\
\text { after } 3 \text { weeks }\end{array}$ & NS* & 200 & NS & 500 \\
\hline Rate of germination & NS & 250 & NS & 450 \\
\hline Radicle length & 100 & 120 & 230 & 325 \\
\hline Shoot yield & 30 & 20 & 65 & 37 \\
\hline Root yield & 10 & 10 & 30 & 22 \\
\hline Survival & NS & 60 & NS & 60 \\
\hline
\end{tabular}

+Statistically significant reduction ( $P \leq 0.05$ ) compared to control treatments with no added boron as determined by nonoverlapping regression line confidence intervals. *NS = no statistically significant $(P \leq 0.05)$ reduction occurred at a boron concentration of $500 \mathrm{ppm}$ for germination or rate of germination or at $100 \mathrm{ppm}$ for survival.

Total germination of Jose tall wheatgrass averaged $83 \%$ and was not reduced even at boron concentrations of $500 \mathrm{ppm}$. Magnar basin wildrye germination was reduced from 92 to $80 \%$ by 200 to $450 \mathrm{ppm}$ boron and then dropped to $47 \%$ at $500 \mathrm{ppm}$ boron. The germination rate of Jose tall wheatgrass was not reduced by boron but that of Magnar basin wildrye decreased at boron concentrations above 250 ppm (Fig. 1). Jose tall wheatgrass had greater absolute radicle growth than Magnar basin wildrye at boron concentrations less than 200 ppm (Fig. 2). Boron concentrations greater than $120 \mathrm{ppm}$ decreased radicle growth of both species but boron decreased relative radicle growth of Jose tall wheatgrass more than that of Magnar basin wildrye; consequently, absolute radicle growth of both species was similar at boron concentrations greater than $200 \mathrm{ppm}$.

Absolute growth of tall wheatgrass shoots and roots (per pot) generally exceeded that of basin wildrye at all boron concentrations (Fig. 3). Leaves of both species exhibited pronounced tip burn and some chlorosis at 80 and $60 \mathrm{ppm}$ of boron, respectively. Root growth of both species was more sensitive to boron than

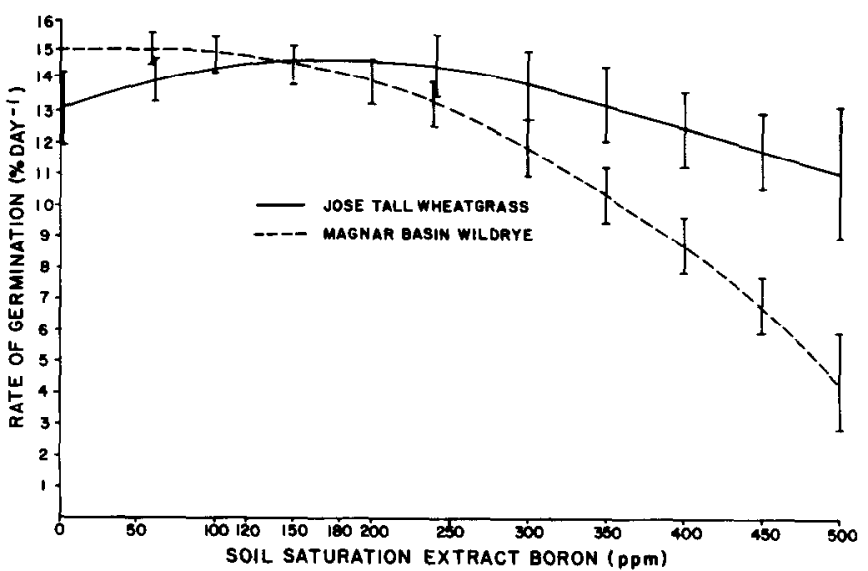

Fig. 1. Rates of germination of Jose tall wheatgrass and Magnar basin wildrye as a third degree polynomial function of soil boron concentration in the saturation extract. Vertical bars indicate confidence limits ( $\mathrm{P} \leq 0.05)$ for the regression lines. $\mathbf{R}^{2}$ values for tall wheatgrass and basin wildrye are 0.14 and 0.74 , respectively, and both regressions are significant at the $\mathrm{P} \leq 0.01$ level.

shoot growth (Table 1). Shoot growth of basin wildrye was more sensitive to increasing boron concentrations than that of tall wheatgrass (Table 1). Root growth of both species was similar in sensitivity to increasing boron concentrations (Fig. 3). Seedling survival of tall wheatgrass in pots in the greenhouse was not affected by boron even at $100 \mathrm{ppm}$, but basin wildrye survival was reduced to 53,45 , and $23 \%$ at boron concentrations of 60,80 , and 100 ppm, respectively.

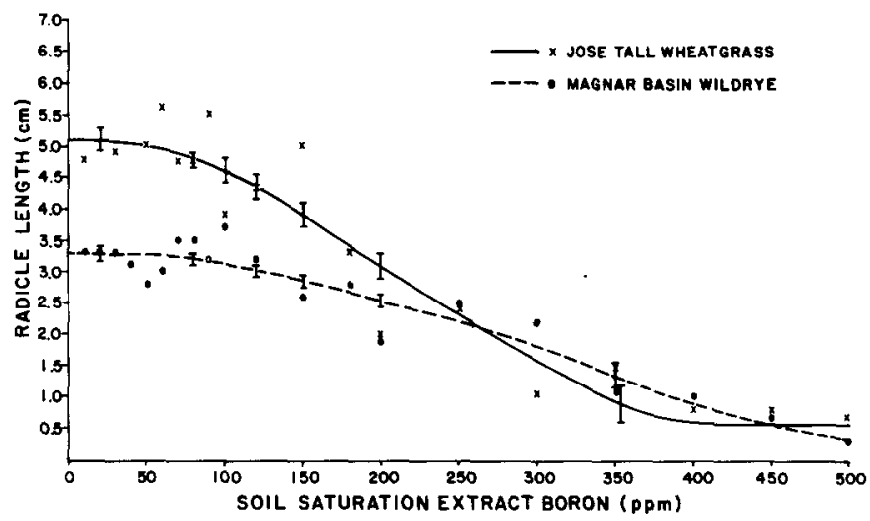

Fig. 2. Radicle length of seedlings of Jose tall wheatgrass and Magnar basin wildrye as a second degree polynomial function of boron concentration in the germinating medium. Vertical bars indicate confidence limits $(\mathrm{P} \leq 0.05)$ for the regression lines and each value is the mean of 20 radicle measurements. $\mathrm{R}^{2}$ values for tall wheatgrass and basin wildrye are 0.59 and 0.48 , respectively, and both regresssions are significant at the $\mathrm{P} \leq 0.05$ level.

Boron content in the saturation extract of a saline soil where Jose tall wheatgrass and Magnar basin wildrye were seeded (Roundy 1985) ranged from 2 to 97 ppm (Table 2). Highest boron

Table 2. Mean boron concentrations of the saturation extract of Gund silt-loam soil samples representing high and low boron concentrations.

\begin{tabular}{lccc}
\hline & & Boron (ppm) & \\
\cline { 3 - 4 } $\begin{array}{c}\text { Depth interval } \\
(\mathrm{cm})\end{array}$ & $\begin{array}{c}\text { High boron } \\
\text { samples }\end{array}$ & $\begin{array}{c}\text { Low boron } \\
\text { samples }\end{array}$ & Range \\
\hline 0.1 & 62 & 4 & $3-97$ \\
$1-5$ & 30 & 6 & $2-42$ \\
$5-10$ & 33 & 6 & $3-44$ \\
$10-15$ & 28 & 5 & $2-40$ \\
\hline
\end{tabular}



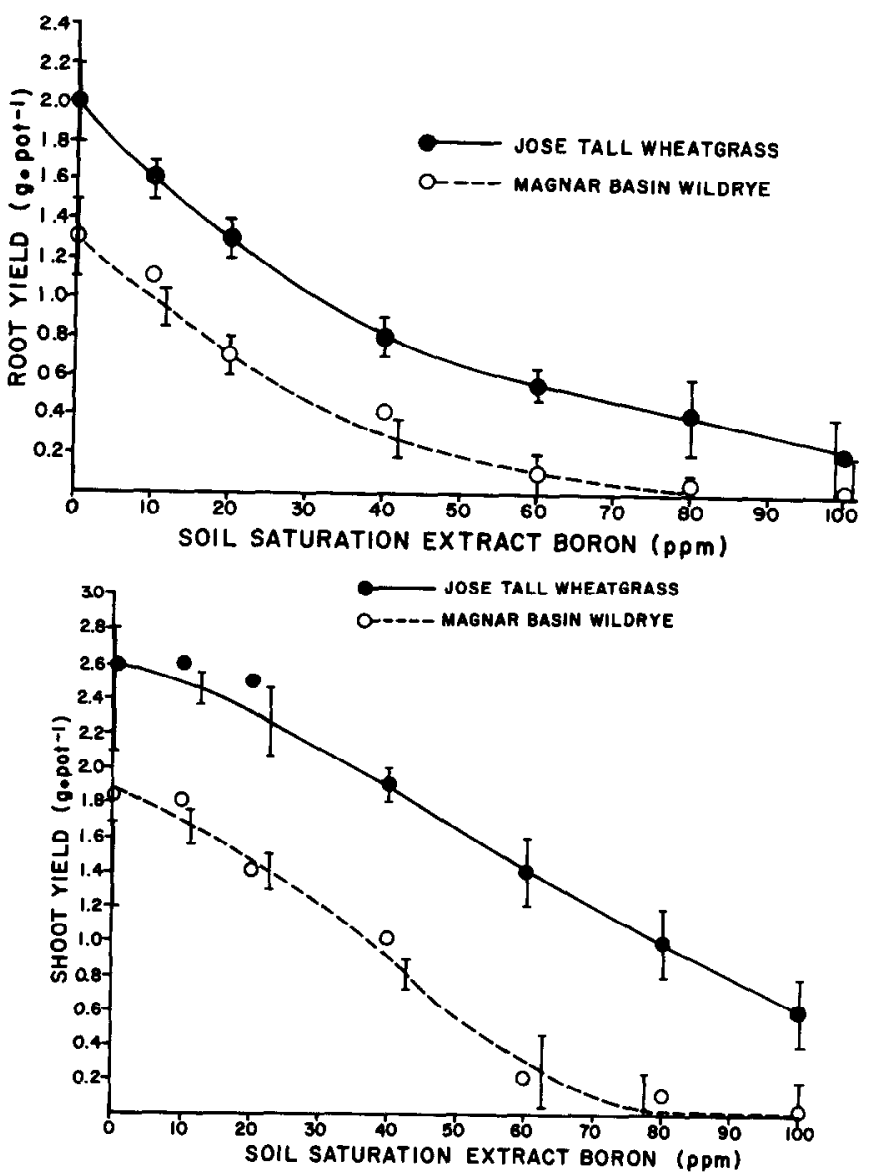

Fig. 3. Dry weight yields of seedling shoots and roots of Jose tall wheatgrass and Magnar basin wildrye as a third degree polynomial function of soil boron concentration in the saturation extract. Vertical bars indicate confidence intervals ( $\mathrm{P} \leq 0.05)$ for the regression lines and each value is the mean of 4 replications. $R^{2}$ values are 0.92 and 0.96 for tall wheatgrass shoots and roots and 0.92 and 0.94 for basin wildrye shoot and roots, respectively. All regressions are significant at the $\mathrm{P} \leq 0.05$ level.

samples averaged about $30 \mathrm{ppm}$ while low boron samples averaged about $5 \mathrm{ppm}$. Boron concentrations in the soil were highly variable horizontally as is the case of other soluble salts (Roundy 1984).

\section{Discussion}

Boron available in the soil solution for uptake by plants is affected by total boron content of the soil, soil water content, soil pH, organic matter content, soil salinity, sesquioxides, clay content, and specific surface area (Becic 1983, Elrashidi and O'Connor 1982). For these reasons it is difficult to estimate soil solution boron concentrations at actual soil water contents from saturation extract concentrations. Changes in availability of boron to plants with changing soil water content also make it difficult to extrapolate plant responses to boron at high soil water contents in laboratory experiments to responses to boron in the field at lower soil water contents. As a saturated soil dries, the boron concentration of the soil increases, even though some salt precipitation and adsorption of boron by the soil occurs. However, saturation extract concentrations of boron in Table 2 probably represent minimal soil solution boron concentrations and may be used as a rough basis for estimating potential boron toxicity in the field.

Both Jose tall wheatgrass and Magnar basin wildrye had high germination rates and total germination at extremely high boron concentrations. The highest boron concentrations in the soil sampled in this study would not reduce rate and total germination of these species, but might slightly reduce radicle growth (Tables 1 and 2). Emergence of these species on saline soils would generally be expected to be limited by low soil osmotic and matric potentials (Roundy et al. 1985) rather than by high boron concentrations.
The boron concentration in the soil that was sampled could directly reduce wheatgrass and basin wildrye shoot and especially root growth. Root growth of both species could be reduced even on the microtopographical areas of low boron concentrations $(5 \mathrm{ppm}$ in the saturation extract) at lower soil water contents. Areas of high boron concentration could be expected to directly reduce survival of Magnar basin wildrye but probably not of Jose tall wheatgrass (Table 1 and 2). Boron may indirectly reduce seedling survival by reducing root growth so that roots are unable to stay below the soil surface drying front. Rollins et al. (1968) attributed failure of tall wheatgrass and basin wildrye to establish on barren interspace soils in Nevada to high total salts and excessive sodium or boron. High seedling mortality of Magnar basin wildrye reported by Roundy (1985) on the moderately saline soil sampled in this study could have been due, in part, to reduced root growth on areas of high boron concentrations. Although both species are more tolerant of boron than many plants (Wilcox 1960), Jose tall wheatgrass has greater absolute growth and its shoot growth is less sensitive to high boron concentrations than Magnar basin wildrye under greenhouse conditions. These differences may allow roots of Jose tall wheatgrass seedlings to stay below the soil drying front and avoid reduced osmotic and matric potentials and increased boron concentrations better than Magnar basin wildrye.

\section{Literature Cited}

Becic, J.N. 1983. Viewpoint: Soil boron guidelines for reclaimed western soils. J. Range Manage. 36:673-674.

Carlson, R.M., and J.L. Paul. Potentiometric determination of boron as tetraflouroborate. Anal. Chem. 40:1292-1295.

Carlson, R.J., and J.L. Paul. 1969. Potentiometric determination of boron in agricultural samples. Soil Sci. 108:266-272.

Carter, D.L., and H.B. Peterson. 1962. Sodic tolerance of tall wheatgrass. Agron. J. 54:382-384.

Dewey, D.R. 1960. Salt tolerance of twenty-five strains of Agropyron. Agron. J. 52:631-635.

Elrashidi, M.A., and G.A. O'Connor. 1982. Boron sorption and desorption in soils. Soil Sci. Soc. Amer. J. 46:27-31.

Evans, R.A., and J.A. Young. 1983. 'Magnar' basin wildrye-germination in relation to temperature. J. Range Manage. 36:395-398.

Hoagland, D.R., and D.I. Arnon. 1938. The water culture method for growing plants without soils. Col. Agr. Exp. Sta. Cir. 347.

Maguire, J.D. 1962. Speed of germination-aid in selection and evaluation of seedling emergence and vigor. Crop Sci. 2:176-177.

Ott, L. 1977. An introduction to statistical methods and data analysis. Duxbury Press. North Scituate, Mass.

Papke, K.G. 1976. Evaporites and brines in Nevada playas. Nevada Bur. of Mines and Geol. Bull. 89. Univ. Nevada, Reno.

Pratt, P.F., E.C. Nord, and F.L. Bair. 1971. Early growth tolerances of grasses, shrubs, and trees to boron in tunnel spoil. USDA Forest Serv. Res. Note PSW-232:1-5.

Rollins, M.B., A.S. Dylla, and R.E. Eckert, Jr. 1968. Soil problems in reseeding a greasewood/rabbitbrush range site. J. Soil and Water Conserv. Serv. 23:138-140.

Roundy, B.A. 1983. Response of basin wildrye and tall wheatgrass seedlings to salination. Agron. J. 75:67-71.

Roundy, B.A. 1984. Estimation of water potential components of saline soils of Great Basin rangelands. Soil Sci. Soc. Amer. J. 48:645-650.

Roundy, B.A. 1985. Emergence and establishment of basin wildrye and tall wheatgrass in relation to moisture and salinity. J. Range Manage. 38:126-131.

Roundy, B.A., J.A. Young, and R.A. Evans. 1985. Germination of basin wildrye and tall wheatgrass in relation to osmotic and matric potentials. Agron. J. 77:129-135.

Schuman, G.E. 1969. Boron tolerance of tall wheatgrass. Agron. J. 61:445-447.

Shannon, M.C. 1978. Testing salt tolerance variability among tall wheatgrass lines. Agron. J. 70:719-722.

Wilcox, L.V. 1960. Boron injury to plants. USDA Info. Bull. 211.

Young, J.A., R.A. Evans, R.O. Gifford, and R.E. Eckert, Jr. 1968. Germination of medusahead in response to osmotic stress. Weed Sci. 16:364-368.

Young, J.A., and R.A. Evans. 1981. Germination of Great Basin wildrye seeds collected from native stands. Agron. J. 73:917-920.

Young, J.A., and R.A. Evans. 1985. Erosion and deposition of fine sediments from playas. J. Arid. Environ. (In press). 